\title{
Alemanha, liberdade e comércio em Maquiavel
}

Igor Ferreira Fontes'

\section{Resumo}

O presente artigo tem por objetivo argumentar que Nicolau Maquiavel admite a possibilidade de o comércio coexistir com a liberdade de uma república. Essa possibilidade seria vislumbrada a partir de seus comentários à Alemanha, elogiada pela preservação da liberdade e cujos cidadãos teriam no comércio sua principal fonte de renda. Para cumprir seu objetivo, o artigo se divide em duas partes: na primeira parte, pretende-se indicar que, para Maquiavel, o fator econômico ocasionador de corrupção não seria exatamente o comércio, mas um excessivo acúmulo de riquezas passível de ocorrer em qualquer atividade econômica; na segunda, busca-se compreender a visão de Maquiavel sobre a Alemanha para, em seguida, investigar a participação dos cidadãos no comércio. A conclusão do artigo é que, para Maquiavel, a coexistência do comércio com a liberdade seria uma possibilidade cuja efetivação dependeria das ordenações da república.

Palavras-chave: Maquiavel. Liberdade. Comércio. República. Alemanha.

\section{Introdução}

A relação entre liberdade e economia de mercado é uma questão que vem ganhando espaço no debate neorrepublicano nos últimos anos. As discussóes entre comunitaristas, neoliberais e neorrepublicanos em torno da concepção de liberdade depararam-se com o problema de como a desigualdade, sobretudo a material, afetaria uma ordem política e social que desejasse fundar-se na liberdade, buscando-se compreender em que medida as estruturas da economia de mercado e a instituição da

I Doutorando em Filosofia pela Universidade Federal de Sergipe (UFS). Mestre e formado em Filosofia pela mesma universidade. O presente artigo é parte da pesquisa desenvolvida no mestrado com bolsa concedida pela Coordenação de Aperfeiçoamento de Pessoal de Nivel Superior (CAPES). E-mail: igor-fontes@outlook.com.

\section{$(\mathrm{oc}) \mathrm{Br}$}

Direito autoral e licença de uso: Este artigo está licenciado sob uma Licença Creative Commons. Com essa licença você pode compartilhar, adaptar, para qualquer fim, desde que atribua a autoria da obra, forneça um link para a licença, e indicar se foram feitas alterações. 
propriedade privada colocariam em risco a vida livre e de que modo seria possível minimizar as formas de dominação oriundas da desigualdade material. Entre aqueles que consideram impossível conciliar liberdade e economia de mercado, e aqueles que concebem a sociedade de mercado como perfeita e sem nenhuma correção a se fazer, poder-se-ia considerar, de modo geral, que para os neorrepublicanos a economia de mercado seria uma grande invenção econômica, mas não a base do modo de vida livre; pois se fosse deixada à própria sorte poderia gerar ou agravar as estruturas de dominação, exigindo que ajustes institucionais sejam feitos para evitar que isso ocorra e direcionar o mercado à expansão da possibilidade de escolhas livres (SILVA, 2016).

Esse debate encontra certa correspondência com o problema da prática do comércio, intensificado a partir da Baixa Idade Média. Segundo Fernand Braudel (2009b), seria possível falar em economia de mercado já na Baixa Idade Média (mesmo que de forma elementar), quando, em 1150, a Europa passou de um consumo agrícola direto para um indireto, originado na circulação dos excedentes da produção rural. As cidades eram abastecidas pelos excedentes da produçáo dos campos e atraíam para si a atividade artesanal, criando um monopólio da fabricação e venda dos produtos industriais; a intensificação desse processo no século XIII teria marcado a passagem decisiva de uma economia doméstica, voltada ao entorno rural, para uma economia de mercado, envolvendo diversas cidades e mercadorias (BRAUDEL, 2009b). A intensificação das operaçóes mercantis foi acompanhada por novas reflexôes em torno do comércio, cuja possibilidade de atuar como fator de corrupção levou teóricos vinculados à tradição aristotélico-tomista, como Girolamo Savonarola, a conceberem o comércio como uma atividade fraudulenta que se desvirtuou quando deixou de prover a subsistência para voltar-se ao mero acúmulo de riquezas; assim, eles defendiam a proibição do comércio e a instauração de uma monarquia ou república agrícolas (FONTES, 2020). Os humanistas cívicos italianos, por sua vez, trataram primeiro de distinguir riqueza e comércio, o qual seria apenas uma das diversas possíveis fontes da riqueza, para apenas na segunda geração humanista surgir uma visão positiva do comércio, vinculando-o à vita activa, ao ensino das virtudes e ao sustento da família (PESANTE, 2000). 
Nicolau Maquiavel é um autor que alguns de seus intérpretes associaram à tradição aristotélico-tomista. Segundo Aldo Fornazieri (2006), Maquiavel se vincularia a essa tradição por entender que o comércio corromperia os costumes de povos virtuosos e, por isso, seria um dos principais fatores da corrupção de uma república. Para o comentador, o exemplo alemão usado por Maquiavel em DT, I, $55^{2}$ demonstraria que a "virtude republicana" seria mais suscetível de perdurar em repúblicas simples e agrárias (dentre as quais também estaria Roma), cujo comércio com outros povos seria inexistente ou de pequena escala, porque o comércio atuaria como um fator de complexificação social e, por consequência, de alteração dos costumes, dificultando a promoção do bem público. A Alemanha apareceria, então, como um exemplo porque seus cidadãos teriam conseguido evitar a aquisiçáo dos costumes corrompidos de seus vizinhos graças ao caráter agrário autárquico de suas cidades, as quais puderam preservar seus costumes simples e tradicionais por tirarem o sustento da terra e evitarem o comércio com outros povos (FORNAZIERI, 2006).

O presente artigo diverge da interpretação de Fornazieri e tem por objetivo argumentar que, para Maquiavel, o comércio náo é necessariamente fator de corrupção e poderia coexistir com a liberdade. A Alemanha não seria um exemplo de república agrária com comércio inexistente ou quase inexistente com outros povos, mas de repúblicas que souberam conciliar a prática do comércio com a liberdade e fazer com que a atividade enriquecesse o publico. Para tal, e a escopo de estruturação, o artigo dividir-se-á em duas partes: primeiro, buscar-se-á problematizar o vínculo estabelecido por Fornazieri entre comércio e corrupção, argumentando que esta poderia advir mais precisamente de uma extrema desigualdade material passível de ocorrer em qualquer atividade produtora de riquezas; em seguida,

2 Os Discursos sobre a primeira década de Tito Lívio serão indicados por DT, seguido do número do Livro e do capítulo. O Príncipe será indicado por IP, seguido do número do capítulo. O Ritratto delle cose della Magna será indicado por RM, seguido do número do parágrafo na edição de Mario Martelli. O Rapporto delle cose della Magna será indicado por RpM, seguido pelo número do parágrafo na edição de Martelli. O Ritratto di cose di Francia será indicado por RF, seguido do número do parágrafo na edição de Martelli. O Discurso sobre as formas de governo de Florença será indicado por DF, seguido do número do parágrafo na edição de Martelli. Para as traduções dos Discorsi e d'O Príncipe usar-se-ão como base, respectivamente, as traduções da Martins Fontes e de Diogo Pires Aurélio reservando-se a liberdade de fazer ajustes quando se julgar pertinente à maior fidelidade do original; as demais traduções são de responsabilidade do autor. 
analisar-se-á o comércio mantido pelas cidades alemãs a fim de mostrar que, mesmo participando do comércio internacional e destacando-se sobretudo no norte da Europa, os alemães são elogiados por Maquiavel por preservarem sua liberdade, seu vivere politico não corrompido, e por manterem os exercícios militares em boa reputação. Portanto, o exemplo alemão mostraria que, para Maquiavel, o comércio não seria necessariamente fator de corrupção e poderia ser praticado numa república, coexistindo com a liberdade.

\section{Comércio, corrupção e desigualdade}

Maquiavel indicaria, de modo mais direto em seu texto, dois fatores originários da corrupção: a perda da virtù militar e do sentido de dignidade da coisa pública, e a desigualdade (BIGNOTTO, 1991).

Quanto ao primeiro fator, teria ocorrido em Roma após a conquista da Ásia, África e Grécia, momento em que os romanos se convenceram da segurança de sua liberdade e de que não haveria mais nenhum inimigo a temer; assim, deixaram de conceder os consulados àqueles que tivessem maior virtù militar para concedê-los primeiro aos que tivessem maior popularidade, depois aos que melhor soubessem lidar (intrattenere) com os homens e, por fim, aos que fossem mais potentes. Nesta última etapa os cidadãos poderosos, predominando nos cargos, passaram a apresentar leis favoráveis não à liberdade comum, mas ao seu poder, mantendo os cidadãos bons e não poderosos fora das magistraturas e com medo dos pode$\operatorname{rosos}(D T, \mathrm{I}, 18)$.

Quanto ao segundo fator, Maquiavel afirma que “[...] tal corrupção e pouca aptidáo à vida livre provêm de uma desigualdade existente na cidade $[\ldots .$. " $(D T, \mathrm{I}, 17)$. Como a república se funda na igualdade e depende desta para se manter $(D T, \mathrm{I}, 55 ; D F, 12)$, a desigualdade seria um fator de corrupção para a república porque seu surgimento corroeria a base sobre a qual a própria república assenta-se, constituindo-se num risco à existência dessa forma de governo ${ }^{3}$. Embora Maquiavel não formule uma definição

3 A desigualdade, contudo, não seria um fator de corrupção para os principados porque estes a teriam como fundamento, logo a existência da desigualdade neles não corroeria seus alicerces (cf. DT, I, 55; DF, I2; SILVA, 2020). 
de desigualdade, Gabriel Pancera entende que se trataria, antes de tudo, da desigualdade política: a república assentar-se-ia sobre a igualdade polí$\mathrm{tica}^{4}$, a qual seria marcada pela não existência de homens que excedam, em poder e importância, os outros habitantes do mesmo território, evitando a subordinação de uns a outros; em um povo marcado pela igualdade os vínculos de obediência não são personalistas, mas estabelecidos pelas leis e instituições, havendo espaços de participação e produção de coesão sociopolítica (PANCERA, 2010; 2013; 2015). A desigualdade nociva à república seria, portanto, a existência de homens que se sobrepusessem aos outros habitantes em poder e os subordinassem, substituindo a obediência às leis pela obediência aos cidadãos mais poderosos - o que permitiria a alguns cidadãos adquirir privilégios político-jurídicos que fragilizariam o funcionamento das ordenaçóes republicanas e criaria uma assimetria de poder no interior da república contrária ao funcionamento do seu regime de leis.

Uma república que desejasse preservar seu vivere politico não corrompido precisaria cuidar para evitar o surgimento da desigualdade política em seu interior, isto é, não admitir que surgissem cidadãos com poder suficiente para subjugar os demais e escapar do alcance das leis. Tal seria, no entendimento de Maquiavel, o que fariam os alemães, que:

[...] não suportam que nenhum de seus cidadãos se apresente nem viva como gentil-homem; aliás, mantêm a igualdade entre seus cidadãos, sendo grandes inimigos dos senhores e gentis-homens que existem naquela província; e, se por acaso lhes caem nas mãos alguns que sejam motivo de corrupção e razão de escândalo, eles os matam [...]. (DT, I, 55).

Essa hostilidade dos alemães aos gentis-homens teria resultado na preservação de seu vivere politico não corrompido porque implicaria numa

4 Entendimento semelhante é tomado por Gisela Bock (1990), segundo a qual a igualdade aludida por Maquiavel não é econômica ou social, mas legal e política; ou seja, não se trata de equalità di sustanze ou della roba, mas equalità di grado ou de' onori. Além da igualdade não ser uma equitativa distribuição de riquezas, Pancera (2010; 2015) acrescenta que a igualdade não seria um traço da natureza humana porque Maquiavel não se preocuparia exatamente em fazer tal tipo de descrição; nem diria respeito direta e imediatamente à igualdade civil, a qual poderia ser vista tanto em repúblicas quanto em principados, por exemplo, nos principados civis, estruturados predominantemente de acordo com um regime de leis. Retomando as considerações de Pancera, José Luiz Ames (2017) endossa que a igualdade à qual Maquiavel se refere seria a igualdade política como igualdade de comando e ausência de privilégio/precedência, concedendo a cada ator social condições para se expressar publicamente - mesmo que em locais diferentes da estrutura político-institucional. 
inimizade à desigualdade representada pelos gentis-homens. As cidades livres alemãs seriam, então, caracterizadas pela ausência de gentis-homens, por uma ordenação política que não se fundaria nos príncipes ou senhores nem obedeceria a eles; essas cidades obedeceriam somente ao imperador alemão - mas, como se verá na próxima seção, graças às suas ordenações, os alemães não o temiam. Assim, a preservação da igualdade política foi um elemento fundamental para a manutenção do vivere politico alemão não corrompido.

Apesar de os gentis-homens representarem uma desigualdade, sobretudo política, as relaçóes assimétricas de poder criadas por eles se originavam da desigualdade material (OSTRENSKY, 2019). Maquiavel define-os como aqueles

[...] que vivem ociosos de suas grandes posses, sem cuidado algum com o cultivo ou com qualquer outro trabalho necessário à subsistência. Esses são perniciosos em todas as repúblicas e em todas as províncias, porém mais perniciosos são aqueles que, além de terem as fortunas de que falamos, comandam em castelos e têm súditos que lhes obedecem [...]. (DT, I, 55).

A existência de gentis-homens numa república consistiria numa ameaça à existência da própria república porque eles criam vínculos de obrigaçóes pessoais: como seu poder se funda em relaçóes de favores que ofertam proteção em troca de lealdade, o domínio direto que os gentis-homens exercem sobre seus súditos contrapóe-se à igualdade exigida por um regime de leis. A desigualdade de poder instaurada pelos gentis-homens rompe os laços da vida civil e tem como uma de suas consequências a formação de partidários e facçóes (PANCERA, 2010. E, para criar tal desigualdade, os gentis-homens usariam suas vastas terras, alicerçando seu poder em sua riqueza privada e concentrando entre si as terras em detrimento do povo (que ficaria na miséria). Os gentis-homens se aproveitariam dessa desigualdade material para oferecerem proteção e um pouco de terra em troca de lealdade e obediência a eles, criando vínculos de obrigaçóes pessoais e adquirindo súditos a partir de sua riqueza privada.

Embora não seja apresentado como gentil-homem, o exemplo de Espúrio Mélio pode ilustrar como a riqueza privada seria usada para se tentar conquistar autoridade extraordinária. Quando Roma se encontrava 
afligida pela fome e as provisóes públicas não eram mais capazes de suprir as necessidades do povo, Espúrio Mélio, homem muito rico, pensou em usar suas terras para produzir uma provisão particular de frumento com o objetivo de alimentar a plebe e, ao agraciá-la, conquistar seu favor. Todavia o senado, suspeitando das intençóes de Espúrio e temendo que ele se fizesse tirano, nomeou um ditador para a questão, que condenou Espúrio à morte (DT, III, 28). Apesar de náo ter obtido êxito, o exemplo de Espúrio ilustra como um cidadão ambicioso buscou adquirir autoridade extraordinária e vínculos personalistas aproveitando-se da desigualdade fundiária que existia em Roma e de uma situaçáo de crise: diante da fome em Roma e da incapacidade das provisóes públicas em nutrir o povo, Espúrio viu a ocasiáo de usar a sua própria riqueza para alimentar a plebe e, com isso, torná-la grata a ele em particular, como se intentasse criar nela um vínculo de lealdade a ele que permitisse-lhe posteriormente usar o favor do povo para obter a autoridade que desejava.

A concentração de terras em Roma pelos patrícios foi um problema que em várias ocasióes o povo tentou solucionar por meio de leis que visassem a reduzir tal concentração. Todavia, como mostra Tito Lívio em sua História de Roma (Livro II, 41-65), em todas as ocasióes, os plebeus encontraram resistência dos nobres e as tentativas de aprovação da lei agrária foram frustradas. Quando os Gracos retomaram essa proposta de lei, cujos principais itens consistiam em limitar o tamanho da propriedade a algumas jeiras e em distribuir entre o povo romano os campos conquistados em guerras, a desigualdade fundiária em Roma e o poder dos nobres tinham crescido de tal modo que não havia mais entre os plebeus a esperança de aprová-las e resolver o problema por vias ordinárias, o que levou grandes e plebeus a se armarem e cada um eleger seu líder, donde provieram as facçôes de Sila e Mário e, posteriormente, as de Pompeu e César (DT, I, 37). As contendas em torno das leis agrárias foram, para Maquiavel, uma das razões da ruína romana, junto à prolongação dos comandos militares que deram reputação àqueles que viriam a encabeçar as facçóes surgidas dessas contendas (DT, III, 24); porém, ele ainda entende que "[...] embora o conflito da lei agrária tenha demorado trezentos anos para acarretar a servidão de Roma, isso teria ocorrido muito mais cedo caso a plebe, seja com essa lei, seja com outros desejos seus, não tivesse sempre refreado a ambição dos nobres [...]" (DT, I, 37). 
Embora o modo como o conflito se desenvolveu a partir da época dos Gracos tenha levado à servidáo romana, a lei agrária, que buscava conter a desigualdade material em Roma, contribuiu para prolongar a duração de seu vivere libero. A lei agrária pôde prolongar o vivere libero porque exercia a função de pôr freios à ambição dos grandes e consistiu numa tentativa popular de resistir por vias ordinárias à concentração das terras entre os nobres, ambição que teria acabado com o vivere libero mais cedo caso não encontrasse nada que a contivesse. Por essa razão Riccardo Breschi (1988) sustenta que a causa da corrupção das repúblicas seria a ambição, pois a desigualdade seria apenas o resultado da livre vazão da ambição humana, que deseja possuir tudo. Segundo Breschi, o excesso de poder conferido a uma única instituição, a degeneração do conflito dos humores e o prolongamento dos comandos militares derivam propriamente do rompimento dos limites impostos à ambição, que leva os humores a aceitarem medidas que contribuam para a dissolução da república. Ainda em seu entendimento, a decadência política romana se iniciou por razóes econômicas intrínsecas à sua estrutura republicana - a concentraçáo fundiária (BRESCHI, 1988).

$\mathrm{O}$ enfoque concedido à desigualdade ocorrida em Roma náo tem por objetivo alegar que uma economia agrária resultaria necessariamente em desigualdade ou corrupção, nem que esses fenômenos não poderiam ocorrer numa economia mercantil. Aliás, o exemplo dos Medici mostra como essa família aproveitou-se da crise fiscal florentina de 1345 e da falência das grandes companhias mercantis da cidade para preencher o vazio deixado por elas e se ocupar das transaçóes financeiras com governos, construindo a enorme riqueza que Cosimo depois usaria para adquirir poder ao empregar a fortuna conquistada no comércio e sobretudo nas finanças para prestar favores aos cidadãos, agraciar a plebe, criar partidários e dificultar a distinção entre seus representantes bancários e os agentes políticos do governo florentino (ARRIGHI, 1996; MAHER, 2017; SILVA, 2020). O objetivo de expor a desigualdade ocorrida em Roma é destacar que há um elemento econômico comum entre os processos de corrupção romano e florentino: o acúmulo de elevada riqueza privada e a conversáo desta em desigualdade política. Em outras palavras, o fator econômico provocador de corrupção não seria uma atividade econômica específica, mas a concentração das riquezas produzidas por meio de alguma atividade econômica. 
O comércio pode ter sido usado pelos Medici para conquistarem a enorme riqueza sobre a qual fundariam seu poder, mas não aparece no caso romano, cujo problema é agrário. Assim, mais do que uma determinada atividade econômica, a corrupção apareceria para Maquiavel como um problema vinculado à concentração de riquezas que possibilitasse a subordinação de alguns cidadãos a outros, transformando uma desigualdade material em desigualdade política. Comércio, agricultura, indústria, finanças ou qualquer outra arte seriam apenas atividades econômicas e, enquanto tais, é inevitável que produzam riquezas; logo, em todas haveria o risco de uma extrema concentração e a possibilidade de servirem como instrumento para que homens ambiciosos buscassem usufruir de uma situação de crise econômica e da excessiva riqueza deles para tomarem o poder, como se percebe pelos exemplos dos Medici (que aproveitaram a quebra da economia florentina para enriquecerem e ocuparem o governo da cidade) e de Espúrio Mélio (que tentou se aproveitar da fome em Roma para comprar o favor da plebe). Enquanto artes, essas atividades dependeriam do uso que se lhes desse e da capacidade das ordenaçóes da república em lidar com a riqueza produzida: Roma e Florença, ao não conseguirem lidar com o agravamento da concentração de riquezas, deixaram que as desigualdades material e política se acentuassem, falhando na imposição de limites à ambição humana.

O elemento econômico comum à corrupção de Roma e Florença é a ambição de homens que se aproveitaram das atividades e crises econômicas de seus tempos para acumularem grandes riquezas e usaram-nas com o propósito de conquistar poder. Maquiavel não atribui uma relação necessária entre determinada atividade econômica e a corrupção, a qual pode ocorrer numa república agrária ou mercantil; o problema residiria, de modo mais preciso, na riqueza concentrada de modo a propiciar a criação de relaçóes de subordinação. O comércio seria um fator de corrupção de uma república quando usado por homens ambiciosos para produzir uma extrema riqueza destinada à criação de partidários e à subordinação dos cidadãos. Contudo, na ausência do comércio, poder-se-ia usar qualquer outra atividade econômica em voga na república para se produzir o mesmo efeito, como ocorreu com a agricultura em Roma. Assim, Maquiavel não parece estar preocupado em indicar determinada atividade econômica como 
corruptora, mas em evitar os efeitos políticos da concentração excessiva de riquezas privadas, independentemente da origem destas - delineia-se uma distinção entre riqueza e atividades econômicas na qual estas seriam apenas diferentes formas possíveis de se produzir aquela. Maquiavel não parece preocupado em indicar certa atividade econômica como preferível ${ }^{5}$, mas em cuidar para que as riquezas produzidas pelas artes que os cidadãos exercem sejam convertidas em riqueza pública, como atesta sua máxima de que as repúblicas bem ordenadas devem manter o publico rico (DT, I, 37). O importante, para Maquiavel, é que as riquezas produzidas pelos cidadãos aumentem o tesouro público e que a república consiga evitar os problemas políticos resultantes da extrema concentração de riquezas.

\section{Liberdade e comércio na Alemanha}

$\mathrm{Na}$ seção anterior buscou-se argumentar que a desigualdade política proveniente da material não seria exclusiva ao comércio e que mesmo uma república agrária poderia se deparar com uma corrupção derivada do acúmulo excessivo de riquezas agrárias. Todavia, apenas isso ainda não seria suficiente para considerar que Maquiavel admitiria a possibilidade de o comércio coexistir com a liberdade, sendo importante buscar em sua obra algum exemplo de república que soube valer-se do comércio. Acredita-se que este exemplo seria a Alemanha, cujas cidades são repetidamente elogiadas por Maquiavel em razão da manutenção de sua liberdade, dos bons costumes e do vivere politico não corrompido; ademais, ele menciona

5 Ao final de seus comentários sobre a questão do comércio em Maquiavel, Fornazieri (2006, p. 243) pondera que as observações de Maquiavel sobre os gentis-homens venezianos abririam "[...] uma janela à possibilidade de articulação estável entre república e comércio [...]”, pois o alicerce mercantil da riqueza dos gentis-homens venezianos os distanciaria da tradicional aristocracia ociosa; assim, "[...] resguardada a preferência de Maquiavel [pelas repúblicas agrárias], a oposição fundamental é entre república e aristocracia, no sentido tradicional do termo [...]". Embora concorde-se com o ponto de que os gentis-homens in fatto são uma ameaça à existência da república, discorda-se da especificação do comércio como um dos principais fatores de corrupção, pois não parece que seja precisamente o comércio um dos principais fatores econômicos de corrupção, mas a concentração excessiva de riquezas, seja qual for a origem destas. Ademais, usar Veneza para indicar a possibilidade de coexistência entre comércio e liberdade dentro do pensamento maquiaveliano pode ser problemático, primeiro, em razão das críticas maquiavelianas às ordenações políticas e militares venezianas; segundo, como se verá na próxima seção, Maquiavel considera que, dentre as províncias de seu tempo, apenas nas cidades livres alemãs poder-se-ia considerar haver liberdade, o que excluiria Veneza. As cidades livres alemãs, por serem libérrimas e contarem com armas próprias, constituiriam um exemplo melhor para se investigar a possibilidade de articulação entre comércio e liberdade. 
em seus textos que a principal fonte de renda dos alemães era a venda de suas mercadorias, o que indica conhecimento por parte dele de que eles exerciam o comércio.

\section{I O vivere politico alemão}

A imagem construída por Maquiavel sobre as cidades alemãs deriva de sua viagem como secretário da segunda chancelaria de Florença a algumas cidades livres no sul da Alemanha. Em dezembro de 1507 ele visitou a Suíça, passando por Genebra, Friburgo, Memmingen e Schaffhausen, e de janeiro a junho de 1508 ele passou seu tempo na regiáo de Tirol (entre o norte da Itália e sul da Áustria), entre as cidades de Innsbruck, Bolzano e Trento (ROSE, 2015). Suas consideraçôes sobre as cidades alemãs dirigem-se à categoria das cidades livres, de modo mais geral, a partir daquilo que ele observou e das informaçóes que adquiriu nas cidades que visitou.

Maquiavel é direto ao afirmar em suas obras que considera a Alemanha como o local de seu tempo onde o vivere libero foi preservado. Primeiro, em $O$ Príncipe, ele escreve que: "As cidades da Alemanha são libérrimas, têm pouco campo à volta, obedecem ao imperador quando querem e não temem a ele nem a qualquer outro potente que tenham nas redondezas [...]" (IP, 10). Nos Discorsi, ele reforça o estado de liberdade das repúblicas alemãs: "[...] E, enquanto em nosso tempo existe apenas uma província em que se possa dizer que há cidades livres, nos tempos antigos todas as províncias tinham povos libérrimos [...]" (DT, II, 2); e destaca ainda os bons costumes nelas ao refletir sobre a obediência à lei por parte de seus cidadãos: "[...] Vê-se muito bem que, na Alemanha, ainda são grandes essa bondade e essa religião em seus povos, graças ao que muitas repúblicas vivem livres e observam as leis de tal modo que ninguém de fora nem de dentro ousa ocupá-las [...]" (DT, I, 55). Por meio dessas passagens, Maquiavel não apenas enfatiza a liberdade das cidades livres alemãs como também as consolida como as únicas de seu tempo que poderiam ser consideradas livres, o que lhes conferiria uma posição de destaque em relação às outras províncias de seu tempo.

Outro aspecto a se destacar das passagens supracitadas, e ligado à manutençáo da liberdade, consiste na preservação da bondade e religião dos 
alemães - ou, de modo um pouco mais geral, dos seus bons costumes. Ao elogiar os costumes dos alemães Maquiavel não o faz sob uma perspectiva propriamente moral, mas sobretudo política: seu elogio dirige-se aos comportamentos dos alemães em relação às leis, à obediência deles às leis mesmo em situaçóes em que poderiam facilmente fraudá-las, como no pagamento de tributos. Os alemães, quando pagavam seus tributos, o faziam sem nenhuma testemunha ou controle, nada assegurando que estivessem pagando a quantia correta; porém, eles não pensavam em fraudá-los, situação que leva Maquiavel a observar a bondade e a religião dos alemães e compará-los aos romanos, que pagavam corretamente os tributos mesmo quando discordavam destes $(D T, \mathrm{I}, 55)$. O correto pagamento dos tributos por parte dos alemães mostraria a bondade e religião deles, porque estariam respeitando o juramento, feito antes do pagamento, de pagar a quantia correta e obedeceriam à lei sem intenção de fraudá-la, o que asseguraria sua eficácia. Tal comportamento dos alemães fez Maquiavel traçar um paralelo entre eles e os romanos quando estes ainda não haviam se corrompido, o que cria uma aproximação entre os costumes desses dois povos e confere aos alemáes maior destaque em relaçáo aos seus contemporâneos, pois além de serem os únicos de seu tempo que poderiam ser considerados livres, sua bondade e religião ainda lembrariam as dos romanos.

Maquiavel também elogia os alemães em razão de suas ordenações e costumes militares. Nas passagens supracitadas, há mençóes ao pouco temor que os alemáes teriam de outros povos (ou mesmo do imperador alemão) e a uma não intenção de outros povos em ocupar as cidades alemãs; isso derivaria de suas fortificações, que levariam qualquer um a considerar que expugnar as cidades seria algo demorado e difícil porque contariam com fossos e muralhas apropriados $(I P, 10)$. Outra razão consistiria nessas cidades contarem com armas próprias, pois os alemães "[...] têm ainda em boa reputação as atividades militares [...]" $(I P, 10)$ e "[...] Em soldados não gastam, porque mantêm seus homens armados e exercitados [...]" (RpM, 8), contando com uma boa artilharia para defender as cidades e com ordenaçóes para manter essas atividades militares $(I P, 10)$. O quadro militar que Maquiavel desenha dos alemáes, portanto, é de povos que construíram boas fortificaçóes para suas cidades, mantiveram as atividades militares em boa reputação e criaram ordenaçôes para treinar seus cidadáos 
e poder usá-los quando as cidades fossem atacadas por outros estados ${ }^{6}$, valendo-se de armas próprias, não de mercenários - medidas que tornariam os alemães capazes de resistir a ataques e desanimariam outros povos de tentar ocupar suas cidades.

A ordenação militar dos alemães contribuiu para outro aspecto que Maquiavel elogia de suas cidades: a manutenção do publico rico. Por manterem seus cidadãos exercitados militarmente e empregarem-nos nas guerras, as cidades alemãs não precisariam gastar contratando soldados mercenários para protegerem-nas, eliminando uma fonte de despesa que consumia os recursos de outros governantes $(R p M, 3-4)$; isso permitia às cidades alemãs destinarem seus recursos a outros fins, como o enriquecimento do erário. A manutenção do publico rico é, para Maquiavel, algo necessário às repúblicas bem ordenadas (DT, I, 37; II, 19; III, 16 e 25) e, como observa Julie Rose (2015, p. 1), manter o publico rico significaria manter o tesouro público com amplos recursos, o que permitiria à república contornar adversidades por um longo período. No caso alemão, suas cidades mantiveram o publico rico por meio de armazéns nos quais conservavam aquilo que era necessário para sobreviverem por um ano inteiro, pois "[...] têm sempre em publico de comer, beber e queimar por um ano; e assim para trabalhar suas indústrias, para poder num assédio alimentar a plebe e aqueles que vivem de trabalhos manuais, por um ano inteiro sem perdas [...]" (RM, 1). Mas a manutenção do publico rico pelas cidades alemãs também consistia numa das razóes para outros povos não intentarem atacá-las, porque sabiam que graças a esses armazéns as cidades alemãs poderiam resistir por um ano inteiro aos assédios sem sofrerem falta de alimentos ou do que fosse necessário à sua subsistência $(I P, 10)$.

Uma particularidade dos alemães ressaltada repetidamente por Maquiavel era que, além do publico, eles também eram ricos no privado. A observaçáo da riqueza privada dos alemães por Maquiavel é acompanhada por mais comentários sobre seus costumes, desta vez salientando o comportamento deles em relação à pobreza:

6 Quando invadidas, porque, para Maquiavel, os alemães não possuíam o desejo de conquistar outros territórios e ampliar seus domínios (cf. DT, II, 19; RM). Assim, os alemães não veriam a necessidade de entrarem em guerra, apenas de se defenderem caso fossem atacados. 
Que os povos sejam ricos no privado, a razão é esta: que vivem como pobres, não edificam, não se adornam e não têm alfaias em casa; e basta-lhes abundar em pão, carne, e ter um local para protegerem-se do frio: e quem não tem outras coisas faz sem elas e não as busca. Gastam dois florins em dez anos e cada um vive, segundo sua vontade, desse modo, e ninguém pensa naquilo que lhe falta, mas naquilo de que há necessidade, e as necessidades deles são muito menores que as nossas. E por esses costumes deles tem-se que não sai dinheiro da província deles, contentando-se com aquilo que sua província produz; e na província deles sempre entra e a ela se levou o dinheiro de quem quer suas coisas [robe], trabalhadas manualmente [lavorate manualmente] - as quais quase enchem toda a Itália. E é tão grande o ganho que fazem porque o grosso do que lhes chega às mãos vem dos trabalhos manuais [delle fatture e opere di mano], com pouco capital deles de outras coisas [robe]. E assim aproveitam esta sua vida rude e livre [...]. (RM, 2).

A condução de uma vida simples e moderada por parte dos alemães seria a razão para que fossem ricos no privado. Por não gastarem seu dinheiro com coisas desnecessárias à sobrevivência e conduzirem uma vida parcimoniosa, na qual viveriam como se fossem pobres, os alemães conseguiriam acumular aquilo que ganhavam e enriqueceriam também no privado. Assim, graças ao seu modo de vida simples e à riqueza privada, os alemães não viveriam em estado de miséria e teriam pelo menos suas condiçôes mínimas de subsistência satisfeitas. Mesmo que não houvesse nessas cidades uma absoluta igualdade material, as diferenças de riquezas entre os alemães não teriam sido suficientes para criar relações de dominação e facçôes, ou seja, os cidadãos das cidades livres alemãs teriam suas condiçôes mínimas de subsistência atendidas e as desigualdades materiais não teriam engendrado desigualdade política ${ }^{7}$.

A passagem supracitada também fornece alguns elementos iniciais sobre as atividades econômicas dos alemães. Primeiro, Maquiavel afirma que os alemães se contentariam com aquilo que sua província produziria, o que

7 Conforme mencionado na nota 4, Maquiavel não defenderia uma igualdade material absoluta, mas admitiria certas diferenças de riquezas entre os cidadãos de uma mesma república desde que não existissem relações de subordinação, obrigações pessoais e desigualdade política (ROSE, 2015; VEGAS, 2013). Ele admite que é necessário haver uma satisfação substancial mínima para a manutenção da igualdade. Satisfação que, no máximo, seria uma condição para a efetivação da igualdade política porque os reflexos da esfera econômica se fariam sentir na ordem política (PANCERA, 2015, p. 149), mas não propõe uma absoluta igualdade material. As diferenças de riquezas constituir-se-iam num problema à república quando seus efeitos se fizessem sentir na ordem política, por exemplo, na criação de relações de dominação ou de facções; mas as diferenças de riquezas poderiam ser toleradas quando não engendrassem dominação. 
é reforçado nos Discorsi quando comenta que os alemães “[...] se contentaram em passar com os bens, em viver dos alimentos e em vestir as lâs que lhes são dados por sua terra $[\ldots]$ " $(D T, \mathrm{I}, 55)$. Embora não faça mençôes a uma abundância de víveres nem a condiçóes tão favoráveis à agricultura, como no caso da França $(R F, 9)$, Maquiavel parece sinalizar para uma produção agrícola alemã que fosse suficiente pelo menos para alimentar a sua própria população, permitindo que os alemães não dependessem do comércio para se nutrirem. De fato, entre o final do quattrocento e início do cinquecento a Alemanha conseguiu, expandindo sua área arável, produzir uma quantidade de grãos necessária para nutrir sua crescente população, em um modelo no qual os campos viviam de suas colheitas e as cidades eram alimentadas pelos excedentes, com os camponeses abastecendo as cidades em um círculo de 20 a $30 \mathrm{~km}$, o que evitava transportes onerosos e a necessidade de se recorrer a estrangeiros; isso fez da Alemanha, junto à França e Suécia, basicamente autossuficiente na produção de cereais, em contraste à Espanha e Itália que não eram autossuficientes e dependiam da importação regular de grãos (BRAUDEL, 1995; MISKIMIN, 1977). Assim, na época de Maquiavel, a Alemanha não dependia do comércio com outros povos para alimentar a sua populaçáo, podendo atender às suas necessidades alimentícias graças à sua produção agrícola.

Entretanto, a principal fonte de renda dos alemães, aquilo que conferia maior entrada de dinheiro às suas cidades, segundo Maquiavel, era a venda das coisas trabalhadas por eles manualmente. $\mathrm{O}$ uso de termos como robe, lavorate manualmente, fatture e opere di mano permite conjecturar que as mercadorias vendidas pelos alemães proviriam de atividades braçais e de confecção, o que remonta à venda de produtos oriundos da indústria, coisas que passaram por algum trabalho de fabricação ou confecção. Poder-se-ia, ainda, acrescentar a observação de que os alemães mantinham em seus armazéns o necessário para aqueles que vivono delle braccia poderem lavorare le industrie loro, a fim de manter sem prejuízos "[...] aquelas atividades que são o nervo e a vida dessa cidade [...]" (IP, 10); ou seja, armazenariam matérias-primas que permitissem a continuidade dos trabalhos deles. A venda dessas mercadorias industriais, dessas robe lavorate manualmente proporcionar-lhes-iam enormes ganhos, donde viria o dinheiro que comporia suas riquezas privadas. Considerando que Maquiavel situa 
a principal fonte da renda dos alemães na venda de mercadorias confeccionadas, seriam, sobretudo, os ganhos deles no comércio a possibilitarem o pagamento dos tributos, direcionando o enriquecimento privado para o crescimento simultâneo do publico. Contudo, dado que Maquiavel náo fornece maiores descriçóes sobre as mercadorias vendidas pelos alemães nem sobre o comércio exercido por eles, resta buscar tais informaçôes em fontes históricas.

\subsection{0 comércio alemão}

De um modo geral, poder-se-ia afirmar que o comércio alemão durante a Baixa Idade Média e o Renascimento consistia especialmente em um comércio de intermediação de mercados, no qual os alemães compravam mercadorias de um povo para transportá-las a outro local e revendê-las a outros povos. Como exemplos dessa atuação, ter-se-iam a Hansa Teutônica cujo papel desempenhado no norte da Europa era comparável ao dos grandes portos italianos no Mediterrâneo ao intermediar o comércio entre a Europa Ocidental e o Oriente ${ }^{8}$; o Fondaco dei tedeschi em Veneza, onde os alemães adquiriam mercadorias das naves venezianas para serem posteriormente revendidas em outras regióes da Europa; e o comércio mantido na Antuérpia, onde os alemães adquiriam mercadorias vendidas por outros povos e levavam-nas para a Alemanha ou para outras regióes da Europa (HARRELD, 2004; PIRENNE, 2012). Mas os alemães também vendiam suas próprias mercadorias, sobretudo tecidos, vinho e metais, como se verá adiante. Como o comércio hanseático centrava-se no norte da Europa e as fontes consultadas fazem poucas mençóes a mercadorias industriais, deixar-se-á de lado o comércio hanseático para focar-se nas cidades livres

8 A Liga Hanseática consistia numa espécie de confederação de cidades marinhas alemãs, fundada a partir do tratado de aliança e livre troca entre as cidades livres de Lübeck e Hamburgo em I230 e cujo domínio marítimo se estendia pelo Báltico, Mar do Norte, Canal da Mancha e chegava ao Mar da Irlanda. As operações da Hansa centravam-se entre as cidades de Bruges, Londres e Novgorod (nas quais estavam suas três bases operativas) e suas principais mercadorias eram produtos alimentícios e matérias-primas, os únicos que seus territórios puramente agrícolas poderiam fornecer ao comércio; por essa razão, apesar de o volume do comércio hanseático superar o do Mediterrâneo, a simplicidade dos negócios e o valor das mercadorias não permitiam grandes lucros - os quais giravam em torno dos $5 \%$. No duecento, a exportação da lã inglesa se tornou quase monopólio da Hansa; entre o quattrocento e o cinquecento, a Hansa se tornou um importante fornecedor de grãos para a Antuérpia (BRAUDEL, 2009b; HARRELD, 2004; PIRENNE, 2012). 
alemãs, em especial as do sul, em razão da experiência maquiaveliana; assim, o comércio alemão será considerado a partir de duas frentes: Fondaco e Antuérpia.

As relaçóes comerciais entre Alemanha e Veneza antecediam a criação do Fondaco dei tedeschi e os negócios mantidos pelo comerciante Bernardus teotonicus fornecem uma valiosa contribuição para esse perío$\mathrm{do}^{9}$. Bernardus era o homem mais potente de Veneza quanto a dinheiro líquido e nenhum contemporâneo seu podia competir com sua riqueza privada, sendo superado apenas pelo doge Pietro Ziani; e dentre os terrenos que possuía, deve-se mencionar o que foi vendido em 1222 para a construção do Fondaco. Quanto à origem de sua riqueza, a fonte mais segura conhecida seria o fornecimento de prata a Veneza, metal fundamental para a economia veneziana mas cujas necessidades não eram atendidas pelas minas mediterrâneas. Bernardus teria conseguido o monopólio do fornecimento de prata a Veneza e extrairia o metal de minas nos Alpes orientais alemães, em Frisacco e Hungria (provavelmente em Rodna, na Transilvânia). Bernardus vendia a prata para Veneza ou usava sua casa bancária no campo de Sáo Bartolomeu para cunhar as moedas e introduzi-las diretamente na economia veneziana. Outra possível fonte de sua riqueza, mas mais incerta, seriam os empréstimos feitos ao duque Leopoldo VI para o pagamento do resgate de Ricardo Coração de Leão (VON STROMER, 1978; ZAORAL, 2011).

O Fondaco dei tedeschi em Veneza é um palácio construído entre 1222 e 1225, vizinho à ponte de Rialto, em razão da intensificação do comércio alemão-veneziano a partir do pactum imperiale e voltado ao alojamento dos comerciantes alemães e depósito de suas mercadorias ${ }^{10}$. Nos séculos seguintes, o comércio alemão-veneziano tornou-se o mais importante para Veneza por fornecer-lhe os metais de que dependia para suas operaçóes no

9 Uma das principais questões nos estudos sobre as relações comerciais alemãs-venezianas pré-Fondaco é o período em que teriam se iniciado. Embora haja especulações de já existirem em meados do século XII, os registros mais sólidos datariam de II77, no pactum imperiale firmado entre Frederico Barbarossa, o papa Alexandre II e as cidades da Liga Lombarda (BARBON, 2007; BRAUDEL, 2009b; VON STROMER, 1978).

10 Por razões de delimitação, serão deixadas de lado as controvérsias em torno das motivações dos venezianos para a criação do Fondaco a fim de se focar nas operações de compra e venda mantidas pelos alemães. Sobre o debate das motivações venezianas ver BARBON, 2007; BRAUDEL, 2009b; LUPPRIAN, 1978. 
Levante, extraídos sobretudo nas minas da Boêmia-Moravia e Hungria; no quattrocento o Fondaco havia se tornado a principal articulação de todas as mercadorias provenientes da parte setentrional dos Alpes destinadas ao Mediterrâneo e ao Oriente e nos primeiros anos do cinquecento o Fondaco era o fulcro do comércio veneziano. Os alemães também eram importantes porque compravam quase todas as mercadorias que os venezianos adquiriam no Levante, fazendo do Fondaco o ponto mais alto e remunerador do comércio de pimenta do reino, onde esta se acumulava antes de ser transportada e revendida a outros alemães. Por sua posição geográfica, Veneza era um destino natural para as mercadorias do sul da Alemanha; assim, tornou-se a cidade italiana mais ligada à Alemanha e à Europa central porque estas, além de serem uma fonte privilegiada de prata, eram os compradores mais certos de algodão, pimenta e especiarias, movimentando o comércio veneziano do fornecimento de metais à compra de suas mercadorias (BARBON, 2007; BRAUDEL, 2009a e 2009b; LUPPRIAN, 1978; RIEDER, 2010; ZAORAL, 2011).

Entre final do quattrocento e início do cinquecento, a região de Tirol - visitada por Maquiavel - tornou-se uma rota mais frequentada pelos comerciantes entre a Alemanha e Veneza. Nesse período a indústria da seda de Tirol desenvolveu-se sobretudo nas cidades de Trento, Rovereto e Ala, que se tornaram os três principais centros produtivos da região por se localizarem no vale do Ádige, uma movimentada rota mercantil que ligava Verona a Tirol e à Alemanha; as roupas de lã e ouro produzidas em Trento, por exemplo, já em 1503 competiam nos mercados da Europa central com as produzidas por Veneza (MOLÀ, 2000). Mas Tirol também havia se tornado uma das regióes de maior mineração na Europa durante o boom de meados quattrocento, tanto na extração quanto no processamento de cobre e prata, transformando-se numa zona mercantil característica de operaçóes minerais. Parte do metal extraído em Tirol era vendido no mercado de Bolzano ou para Veneza. As minas de Tirol ainda serviam para a criação de arsenais, como no caso da cidade de Innsbruck, cujas armas, lanças e espadas eram fabricadas a partir dos metais extraídos nas minas de Tirol, especialmente em Schwaz (KELLENBENZ, 1990; LONG, 2011, 2015). Assim, a região de Tirol, visitada por Maquiavel, era caracterizada como um todo por ser uma movimentada rota do comércio alemáo-veneziano, 
em especial graças às oportunidades mercantis que a região oferecia; quanto às cidades, Trento era uma zona mercantil caracterizada pelos tecidos e Bolzano e Innsbruck eram zonas caracterizadas pelo comércio de metais, com destaque aos arsenais de Innsbruck.

Quanto ao comércio mantido pelos alemães na Antuérpia, as cidades do norte da Alemanha participavam do comércio internacional desde o século XI, sobretudo por meio de Colônia, operando em Tiel, Bruges e Antuérpia. Todavia, esta ganhou gradativa relevância a partir do duecento graças à comercialização de lá inglesa até tornar-se, no quattrocento, o mercado continental para as roupas de lá inglesa e para os bens oriundos da cidade livre de Colônia e de outras cidades do norte da Alemanha. Colônia tornou-se o parceiro comercial mais importante da Antuérpia graças à demanda de panos ingleses nos mercados alemães e, no final do quattrocento, as exportaçóes de tecidos para a Antuérpia atingiram seu auge: a indústria têxtil alemã, sobretudo Colônia, baseava-se na produção de tirtey, uma combinação de lã e linho, e as roupas confeccionadas em Colônia usando tecidos ingleses tornaram-se populares na Antuérpia. Mas Colônia também era o destino mais importante das mercadorias exportadas da Antuérpia para as cidades do norte da Alemanha, mercadorias enviadas primeiro para Colônia e de onde seriam redistribuídas para as outras cidades. Além dos tecidos, os alemães também levavam para a Antuérpia o vinho do Reno (a mercadoria mais exportada oriunda do norte da Alemanha) e produtos secos, que consistiam numa variedade não determinada de bens armazenados no mesmo local, como peles, roupas, especiarias, cânhamo, madeira e papel. As cidades do norte da Alemanha, de modo geral, também exportavam para a Antuérpia alimentos e metais, especialmente calamina e cobre extraídos na região próxima à cidade livre de Aachen (HARRELD, 2004; MISKIMIN, 1977; PIRENNE, 2012).

A maior parte dos comerciantes do sul da Alemanha só foi à Antuérpia no final do quattrocento, em razáo do comércio de tecidos ingleses e da ida das grandes companhias mercantis. Eles compravam e revendiam especiarias e outros tipos de mercadorias vendidas pelos italianos e comerciantes de Bruges, destacando-se as especiarias trazidas do Levante pelos venezianos e compradas pelos alemães tanto em cidades alemãs quanto 
italianas para enviarem ao norte da Europa pelo rio Brenner. A cidade livre de Nuremberg, por exemplo, era uma das principais cidades que vendiam à Antuérpia as especiarias trazidas do Levante pelos venezianos. Mas os comerciantes alemães presentes em Lisboa vincularam-se às expediçóes portuguesas nas Américas, o que forneceu aos alemães as especiarias que posteriormente revenderiam na Europa nórdica e central. Os alemães ainda exportavam para a Antuérpia cerca de cem mil peças de fustians por ano, fabricados no sul e oeste da Alemanha (principalmente nas cidades livres de Ulm e Augsburgo), e quase todos seriam posteriormente reexportados para a Inglaterra; e na Antuérpia os comerciantes alemães obtinham produtos de lã inglesa que seriam posteriormente vendidos na cidade livre de Frankfurt (a qual, junto a Nuremberg, tornaram-se no cinquecento os principais destinos alemães para o açúcar produzido nas ilhas de São Tomé, Madeira e Canárias). Mas a principal mercadoria eram os metais, que consistiam numa larga parte dos negócios dos comerciantes do sul da Alemanha, com destaque inicial ao cobre, cujas vendas foram impulsionadas pela determinação do vice-rei português Francisco de Almeida em 1508 de que o pagamento da pimenta indiana deveria ser constituído por $3 / 4$ de ouro e $1 / 4$ de cobre, elevando a demanda por este metal na Antuérpia; outro metal importante para os negócios dos alemáes do sul era a prata, que entre o duecento e aproximadamente 1550 se valorizou ao ser usada por príncipes para a realizaçáo de seus desígnios, o que favoreceu os negócios daqueles que a detinham, como os comerciantes de Augsburgo, os donos das minas de prata da Boêmia e Alpes e, sobretudo, os Fugger (BRAUDEL, 1995; HARRELD, 2004).

A partir dessas consideraçóes sobre o comércio alemão, é possível retornar ao texto de Maquiavel. As opere di mano alemáes, ou robe lavorate manualmente, às quais ele alude, provavelmente se refeririam aos metais e tecidos, visto que eram mercadorias trabalhadas e confeccionadas pelos alemães para serem posteriormente vendidas no resto da Europa. Os tecidos ingleses finalizados, por exemplo, em Colônia, eram vendidos na Antuérpia ou transportados pelos comerciantes alemáes para os locais em que seus negócios se estendiam; e os metais trabalhados pelas cidades do sul da Alemanha, mesmo que extraídos em outras regiōes, eram transportados principalmente para Veneza e Antuérpia. Os metais e tecidos também 
se destacavam nas cidades e na região visitadas por Maquiavel, sobretudo Innsbruck e Trento que se caracterizaram, respectivamente, como zonas mercantis de arsenais e tecidos, ou seja, pela venda das mercadorias de suas indústrias minerárias e têxteis. Trento e, de modo mais geral, a região de Tirol ainda se destacavam como uma rota mercantil que ligava a Alemanha a Veneza e à Itália, rota que servia para os alemães enviarem as mercadorias compradas no Fondaco ao resto da Europa (ou à Antuérpia) ou para enviarem suas mercadorias que seriam vendidas em Veneza ou no resto da Itália. Embora vendessem outras coisas, como vinhos e especiarias, é à comercialização daquelas opere di mano que Maquiavel atribui a maior parte da renda dos alemáes, seria a venda das mercadorias industriais a enriquecê-los. Assim, mesmo que não forneça grandes detalhes sobre seu comércio, Maquiavel sabia que os alemáes o praticavam e situa o comércio como a principal fonte da renda deles, embora não dependessem dessa atividade para suprirem a sua subsistência porque conseguiam alimentar-se com aquilo que era produzido por sua província.

\section{Considerações finais}

Retornando à interpretação de Fornazieri (2006) exposta na introdução deste artigo, a divergência em relação à interpretação dele reside na leitura das cidades livres alemâs como repúblicas agrárias que conseguiram preservar sua liberdade, igualdade e bons costumes porque evitaram o comércio, o qual seria um fator de corrupção das repúblicas. Conforme se argumentou ao longo do artigo, o fator econômico corruptor das repúblicas não seria precisamente uma atividade econômica, mas uma extrema desigualdade de riquezas independentemente da origem destas. Ademais, observa-se que - embora, de fato, exercessem a agricultura e não dependessem do comércio para prover à sua subsistência, uma vez que eram autossuficientes em grãos - os alemães praticavam simultaneamente o comércio e usavam-no como uma forma de enriquecimento; assim, a participaçáo dos alemães no comércio internacional não era pequena, comparando-se ao comércio do Mediterrâneo em volume e estendendo-se por toda a Europa. Os alemáes, portanto, seriam um exemplo de povos que souberam conciliar comércio e agricultura, valendo-se desta para não dependerem da importação de alimentos e daquele para enriquecerem. 
A participação dos alemães no comércio internacional e os elogios maquiavelianos ao vivere politico alemáo também mostram a possibilidade de o comércio coexistir com a liberdade. Os alemães, mesmo praticando o comércio, mantiveram os exercícios militares em boa reputação e sua população exercitada; preservaram a igualdade e o ódio aos gentis-homens, o que contribuiu para a manutenção de seu vivere politico não corrompido; e são os únicos de seu tempo que Maquiavel considera livres. A prática do comércio pelos alemães coexistia com sua liberdade e seus bons costumes e na época de Maquiavel a participação deles no comércio internacional não era novidade, ocorrendo havia já alguns séculos no caso de algumas cidades. Não se pretende afirmar que para Maquiavel o comércio é necessário para o vivere libero, mas que a coexistência deles se insere no campo da possibilidade: o comércio não é necessariamente incompatível com o vivere libero, nem é a base deste. A coexistência do comércio com a liberdade é uma possibilidade cuja efetivação depende de as ordenações republicanas destinarem a riqueza produzida no comércio ao enriquecimento do publico e criarem mecanismos que evitem o uso das riquezas produzidas pelo comércio na criação de relaçóes de subordinação.

A produção de riquezas pode ser intrínseca a uma atividade econômica, mas a concentração delas e a criação de relaçóes de dominação podem ser combatidas por uma república. Aliás, como afirma Maquiavel nos Discorsi, o acúmulo de tão desmesurada riqueza só poderia ocorrer numa república já corrompida:

[...] para que um cidadão consiga ser ofensivo e apoderar-se de uma autoridade extraordinária, precisaria ter muitas qualidades que nunca poderia ter numa república não corrompida, pois precisa ser riquíssimo e ter muitos adeptos e partidários, os quais não pode ter onde há observância das leis [...]. (DT, I, 34).

O acúmulo desmesurado de riquezas, seja qual for a fonte destas, ocorreria numa república que não tivesse tomado precauçóes contra a ameaça representada por tais cidadãos e permitisse que essa desigualdade se instaurasse em seu interior; portanto, caberia à república ordenar-se de modo a evitar a possibilidade de corrupção pela riqueza produzida por uma arte, seja esta comércio, agricultura, indústria, finanças ou qualquer outra. Os efeitos políticos de uma arte dependeriam do direcionamento que lhe 
fosse conferido pelas ordenaçóes, podendo contribuir ao enriquecimento do publico ou à corrupção.

A corrupção pelo uso que se faz do comércio é uma possibilidade, como o é para a agricultura ou qualquer outra arte; mas é possibilidade que pode ser combatida pelas ordenaçóes. O comércio é um fator de corrupção quando usado para produzir desigualdade política a partir da material. Mas, o exemplo romano mostra que, na ausência do comércio, pode-se obter o mesmo resultado por outros meios, inclusive na agricultura. Porém quando é bem ordenado e voltado ao enriquecimento do publico, o comércio pode coexistir com a liberdade da república. Isso distancia Maquiavel da posição assumida por Savonarola em sua maior influência aristotélico-tomista por criar a possibilidade de o comércio ser praticado pelos cidadãos de uma república em conformidade com o vivere libero e aproxima-o da tradição humanista que distingue riqueza de comércio, concebendo este como apenas uma das possíveis fontes daquela. Sendo uma atividade econômica uma forma de produzir riqueza, o elemento econômico comum a todas as atividades que corroeria a igualdade sobre a qual a república assenta-se é a concentração de riquezas que produzisse uma situação na qual os cidadãos, ao não terem suas condiçôes básicas de subsistência atendidas, se vissem obrigados a se submeterem a outros cidadãos (os mais ricos), substituindo a obediência às leis da república pela obediência àquele cidadão. $\mathrm{O}$ comércio pode coexistir com a liberdade; mas, como qualquer outra atividade econômica, demanda que a república cuide de evitar que as diferenças de riquezas entre os cidadãos se reflitam na esfera política.

\section{Referências}

ARRIGHI, G. O longo século XX: dinheiro, poder e as origens do nosso tempo. Tradução de Vera Ribeiro. Rio de Janeiro: Contraponto; São Paulo: Editora Unesp, 1996.

AMES, J. L. Conflito e liberdade: a vida política para Maquiavel. Curitiba: Editora CRV, 2017.

BARBON, F. H. I segni dei mercanti a Venezia nel Fondaco dei tedeschi. Atti e memorie dell'Ateneo di Treviso, n. 23, p. 103-122, 2007.

BIGNOTTO, N. Maquiavel republicano. São Paulo: Loyola, 1991.

BOCK, G. Civil discord in Machiavelli's Istorie Fiorentine. In: BOCK, G.; SKINNER, Q.; VIROLI, M. (ed.). Machiavelli and republicanism. Cambridge: Cambridge University Press, 1990, p. 181-201. 
BRAUDEL, F. Civilizaçáo material, economia e capitalismo, séculos XV-XVIII: as estruturas do cotidiano. Vol. 1. Tradução de Telma Costa. São Paulo: Martins Fontes, 1995.

BRAUDEL, F. Civilizaçáo material, economia e capitalismo, séculos XV-XVIII: os jogos das trocas. Vol. 2. 2. ed. Tradução de Telma Costa. São Paulo: WMF Martins Fontes, 2009a.

BRAUDEL, F. Civilizaçáo material, economia e capitalismo, séculos XV-XVIII: o tempo do mundo, vol. 3. 2. ed. Tradução de Telma Costa. São Paulo: WMF Martins Fontes, 2009b.

BRESCHI, R. Il concetto di "corruzione" nei "Discorsi sopra la prima deca di Tito Livio". Studi Storici, ano 29, n. 3, p. 707-735, 1988.

FONTES, I. F. A relaçáo entre comércio e instituiçóes republicanas em Maquiavel. Orientadora: Flávia Roberta Benevenuto de Souza 2020. 197 f. Dissertação (Mestrado em Filosofia) - Programa de Pós-Graduação em Filosofia, Universidade Federal de Sergipe, São Cristóvão, 2020.

FORNAZIERI, A. Maquiavel e o bom governo. Orientador: Cláudio Vouga 2006. 288 f. Tese (Doutorado em Ciência Política) - Programa de Pós-Graduação em Ciência Política, Universidade de São Paulo, São Paulo, 2006.

HARRELD, D. J. High Germans in the Low Countries: German merchants and commerce in Golden Age Antwerp. Leiden; Boston: Brill, 2004.

KELLENBENZ, H. Le miniere di Primiero e le relazioni dei Fugger con Venezia nel quattrocento. Atti della Accademia roveretana degli Agiati, v. 28, n. 6, p. 365-385, 1990.

LIVIO, T. Storie: libri I-V. Tradução de Luciano Perelli. Torino: UTET, 1974.

LONG, P. O. Artisan/Practitioners and the rise of the New Sciences, 1400-1600. Corvallis: Oregon State University Press, 2011.

LONG, P. O. Trading zones in Early Modern Europe. The History of Science Society, v. 106, n. 4, p. 840-847, 2015.

LUPPRIAN, K.-E. Il Fondaco dei tedeschi e la sua funzione di controllo del commercio tedesco a Venezia. Centro Tedesco di Studi Veneziani, Venezia, quaderni 6, p. 3-20, 1978.

MACHIAVELLI, N. Tutte le opere. A cura di Mario martelli. Firenze: Sansoni, 1971.

MAHER, A. The power of "wealth, nobility and men:" inequality and corruption in Machiavelli's Florentine Histories. European Journal of Political Theory, v. 19, n. 4, p. 512-531, sept. 2017.

MAQUIAVEL, N. Discursos sobre a primeira década de Tito Lívio. São Paulo: Martins Fontes, 2007.

MAQUIAVEL, N. O Príncipe. Tradução de Diogo Pires Aurélio. São Paulo: Ed. 34, 2017.

MISKIMIN, H. A. The economy of later Renaissance Europe: 1460-1600. Cambridge: Cambridge University Press, 1977.

MOLÀ, L. The silk industry of Renaissance Venice. Baltimore: The Johns Hopkins University Press, 2000. 
OSTRENSKY, E. Maquiavel: a ambição e o dilema das leis agrárias. Lua Nova, n. 107, p. 55-90, 2019.

PANCERA, C. G. K. Maquiavel entre repúblicas. Belo Horizonte: Editora UFMG, 2010.

PANCERA, C. G. K. Liberdade e igualdade no pensamento político maquiaveliano. In: ADVERSE, H. (org.). Filosofia política no renascimento italiano. São Paulo: Annablume; Belo Horizonte: Programa de Pós-Graduação em Filosofia da UFMG, 2013. p. 145-170.

PANCERA, C. G. K. Diálogos em torno da igualdade. Ponderações sobre as objeções de J. L. Ames. In: ADVERSE, H. (org.). Reflexóes sobre Maquiavel: 500 anos de O Príncipe. São Paulo: Loyola, 2015. p. 153-170.

PESANTE, M. L. Il commercio nella repubblica. Quaderni Storici, v. 105, n. 3, p. 655-695, 2000.

PIRENNE, H. Storia economica e sociale del Medioevo. Tradução de Maurizio Grasso. Roma: Newton Compton, 2012. Edizione digitale.

RIEDER, M. Cosmopoliti sull'Adriatico. Mercanti ed industriali a Venezia e Trieste. Qualestoria - Rivista di storia contemporanea, ano XXXVIII, n. 1, p. 99-133, 2010.

ROSE, J. L. 'Keep the Citizens Poor': Machiavelli's prescription for republican poverty. Political Studies, v. 64, n. 3, p. 1-14, 2015.

SILVA, R. Da honra ao patrimônio: conflito social e instituiçóes políticas nos Discorsi de Maquiavel. Revista Brasileira de Ciência Política, Brasília, n. 12, p. 43-66, 2013.

SILVA, R. Liberdade, desigualdade e dominação: a economia política do neorrepublicanismo. In: MIGUEL, L. F. (org.). Desigualdades e democracia: o debate da teoria política. Sáo Paulo: Editora Unesp, 2016. p. 137-170.

SILVA, R. Desigualdade e corrupção no republicanismo de Maquiavel. Dados, Rio de Janeiro, v. 63, n. 3, p. 1-37, 2020.

VEGAS, J. L. C. Ciudad rica y ciudadanos pobres. La consideración de la riqueza en el republicanismo florentino. Ingenium - Revista de historia del pensamiento moderno, n. 7, p. 71-91, 2013.

VON STROMER, W. Bernardus teotonicus e i rapporti commerciali tra la Germania Meridionale e Venezia prima della istituzione del Fondaco dei Tedeschi. Centro Tedesco di Studi Veneziani, Venezia, quaderni 8, p. 3-33, 1978.

ZAORAL, R. Silver and glass in medieval trade and cultural exchange between Venice and the Bohemian Kingdom. The Czech Historical Review, v. 109, n. 2, p. 284-310, 2011. 


\section{Germany, liberty and trade in Machiavelli}

\section{Abstract}

This paper aims to postulate that Niccolò Machiavelli admits the possibility that trade can coexist with the freedom of a republic. This possibility would be glimpsed from his comments about Germany, praised for the preservation of freedom and for the citizens achieving trade their main source of income. To fulfill its objective, the paper is divided into two parts: in the first one we intend to indicate that, for Machiavelli, the economic factor causing corruption would not necessarily be found in trade, but on an excessive accumulation of wealth that can occur in any economic activity; in the second section, we seek to understand Machiavelli's view of Germany and then investigate the participation of its citizens in trade. The conclusion of the paper is that, for Machiavelli, the coexistence of trade with liberty would be a possibility whose effectiveness would depend on the orders of the republic.

Keywords: Machiavelli. Liberty. Trade. Republic. Germany. 